\title{
Diagnostic Discordance-based Inferences Regarding Imaging Modalities in Children with a Preliminary Diagnosis of Choledochal Cyst: Clinical Experience and Review of Literature Koledok Kisti Ön Tanısı Konan Çocuklarda Görüntüleme Modalitelerine Illişkin Tanısal Uyumsuzluk Temelli Çıkarımlar: Klinik Deneyim ve Literatür Taraması
}

Esra Ozcakir (0000-0002-0773-7430), Mete Kaya (0000-0002-8877-5737)

University of Health Sciences, Bursa Medical Faculty, Department of Pediatric Surgery, Bursa, Turkey

Keywords

Choledochal cyst, magnetic resonance cholangiopancreatography, MRCP, intraoperative cholangiography, IOC

\section{Anahtar kelimeler \\ Koledok kisti, manyetik rezonans kolanjiyopankreatografi, MRCP, intraoperatif kolanjiyografi, İOK}

Received/Geliş Tarihi : 02.02.2021 Accepted/Kabul Tarihi : 25.04.2021

DOI:10.4274/jcp.2021.0024

Address for Correspondence/Yazışma Adresi: Esra Ozcakir Assist. Prof., University of Health Sciences, Bursa Medical Faculty, Department of Pediatric Surgery, Bursa, Turkey

E-mail: dresramermer@hotmail.com

\begin{abstract}
Introduction: Definitive diagnosis is essential for the medical and surgical management of pediatric patients with a preliminary diagnosis of a choledochal cyst. Our study aimed to investigate the roles of Magnetic Resonance Cholangiopancreatography (MRCP), Intraoperative Cholangiography (IOC) in differential and definitive diagnosis of choledochal cyst by comparing their results with the intraoperative gross pathological appearance.

Materials and Methods: The medical records of seven pediatric patients preliminary diagnosed with choledochal cyst between May 2014 and January 2021 in our clinic, were retrospectively reviewed. We investigated the clinical characteristics, the MRCP and IOC results, and compared their results with the intraoperative gross pathological findings of patients with preliminarily diagnosed choledochal cyst. We evaluated the outcomes involving the preliminary diagnosis and subtype of choledochal cyst with MRCP preoperatively and with IOC and gross pathological findings intraoperatively.

Results: Six patients had undergone a laparotomy and IOC procedure, and their results were: in three, the MRCP and IOC results were consistent, both revealing a Type-I choledochal cyst; in another patient, MRCP revealed a TypeIV choledochal cyst, whereas IOC showed a Type-I choledochal cyst; one patient reported having a Type-II choledochal cyst in MRCP turned out to have a duodenal duplication cyst intraoperatively; the sixth operated patient had an MRCP result of Type-I choledochal cyst, but the IOC was consistent with biliary atresia and severe hydropic bile stasis. The last child was a non-operated patient whose MRCP revealed a Type-I choledochal cyst whereas contrast-enhanced liver magnetic resonance showed a simple liver cyst.

Conclusions: Even though MRCP is valuable regarding choledochal cyst's differential diagnosis, we should confirm its diagnosis by IOC and intraoperative gross pathological view because other pathologies might appear similar to choledochal cyst in MRCP.
\end{abstract}

Öz

Giriş: Koledok kistlerinin değerlendirilmesinde kullanılan Manyetik rezonans kolanjiyopankreatografi (MRCP) Koledok kist'nın tiplerini belirleyen en önemli görüntüleme çalışmasıdır. Koledok kisti ön tanısı ile başvuran çocuk hastalarda uygulanacak cerrahi yaklaşımı belirlemek için kesin tanı şarttır. Çalışmamız, 
Koledok kist ön tanısı ile değerlendirdiğimiz hastaların, ayırıcı ve kesin tanısında intraoperatif bulgular eşliğinde, Manyetik Rezonans Kolanjiyopankreatografi (MRCP) ve İntraoperatif Kolanjiyografi (IOC) 'nin rolünü araştırmayı amaçladı.

Gereç ve Yöntem: Kliniğimizde Mayıs 2014 - Ocak 2021 tarihleri arasında koledok kisti ön tanısı almış yedi pediatrik hastanın tıbbi kayıtları retrospektif olarak incelendi. Önceden koledok kisti tanısı almış hastaların klinik özellikleri, MRCP ve IOC sonuçlarını araştırdık ve sonuçlarını intraoperatif brüt patolojik bulgular ile karşılaştırdık. Koledok kistinin ön tanı ve alt tipini içeren sonuçları ameliyat öncesi MRCP, intraoperatif IOC ve brüt patolojik bulgular ile değerlendirdik.

Bulgular: Yedi hastadan altısına laparotomi ve IOC prosedürü uygulandı. Üç hastada MRCP ve IOC sonuçları tutarlıydı, her ikisi de bir Tip-I koledok kistini doğruladı. Bir hastada, MRCP bir Tip-IV koledok kisti ortaya koyarken, bu hastada IOC Tip-I koledok kisti olduğunu gösterdi; MRCP'de Tip-II koledok kisti olduğunu bildiren bir hastada intraoperatif duodenal duplikasyon kisti olduğu görüldü; ameliyat edilen altıncı hastada Tip-I koledokal kist MRCP sonucu vardı, ancak laparatomide çekilen IOC biliyer atrezi ve şiddetli hidropik safra stazı ile uyumluydu. Diğer bir hastada MRCPTip-I koledok kisti tariflerken, hastanın çekilen hepatosite spesifik kontrastlı manyetik rezonans görüntülemesi basit karaciğer kisti ile uyumlu olduğu için hasta cerrahiye alınmadı. Sonuç: MRCP, koledok kistinin ayırıcı tanısı açısından oldukça değerli olsa da, hastaların kesin tanısı için laparatomi sırasındaki değerlendirme ve IOC ile doğrulama gerekmektedir. Batın içi farklı patolojilerin de MRCP'de koledok kisti ile benzer görünüm sergileyebileceği unutulmamalıdır.

\section{Introduction}

Conjugated hyperbilirubinemia can be because of medical and surgical causes, and if neglected, can cause severe and irreversible hepatic damage, thus necessitating timely diagnosis of surgical causes such as biliary atresia and choledochal malformations in neonatal and pediatric age groups [1].

A choledochal cyst (CC), which is among the surgical causes of conjugated hyperbilirubinemia, is a rare congenital anomaly characterized by fusiform or spherical shaped dilatations of extrahepatic bile ducts, the former being more common in infants [2]. Vater first described CC in 1723, Alonso-Lej introduced its classification into three subtypes in 1959 , and Todani changed this classification to involve five cyst subcategories regarding the number, localization, size, and ultrastructure of the cystic dilatations $[3,4]$. A recently published global review of Friedmacher et al. discussed choledochal cysts in the spectrum of choledochal malformations characterized by anomalous dilatation of the biliary tract with no acute obstruction [5]. It has been reported a choledochal cyst typically manifests itself with jaundice, abdominal pain, and a palpable right upper quadrant mass, described as the classical triad; however, contradictory reports exist in the literature, claiming that the triad was present in only $6 \%$ of total cases. Besides, there are also asymptomatic and incidentally diagnosed CC cases [6]. On the other hand, a choledochal cyst might sometimes present with severe clinical features such as pancreatitis, cholangitis, and biliary cirrhosis.

The initial diagnostic imaging method to differentiate and identify the cause of unconjugated hyperbilirubinemia was found to be ultrasonography (USG). Computed tomography (CT) and radionuclide scintigraphy were also valid methods used for this purpose. However, even though the pathology was identified to some extent, those three imaging methods were inadequate to reveal the pancreaticobiliary ductal system's anatomy, particularly when a surgical intervention was necessary. Magnetic Resonance Cholangiopancreatography (MRCP) has recently been reported as a more accurate method for providing sufficient data regarding pancreaticobiliary anatomy [7]. Intraoperative cholangiography (IOC) has been reported as the most commonly used imaging modality for the pathology's definitive diagnosis and pancreaticobiliary system assessment. In their study investigating the imaging modalities in their 117 pediatric CC cases, Saito et al. reported that using the combination of MRCP and IOC revealed sufficient information on pancreaticobiliary anatomy [7].

Overall, it is known that detected ductal dilatation or cyst formation - which also appears in other pathologies - requires a different treatment procedure. The critical point is that, due to the false diagnose of $\mathrm{CC}$, it may be misinterpreted in MRCP. Therefore, in order to plan the treatment procedure correctly, the exact pathologic anatomy must be identified by imaging modalities in patients with preliminary diagnosed CC.

Our study aimed to present our cases preliminarily diagnosed with $\mathrm{CC}$ and to identify the roles of MRCP and IOC in differential and definitive diagnosis of the pathology by investigating the congruence of MRCP and IOC results with the intraoperative gross pathological appearance. 


\section{Materials and Methods}

This retrospective study was conducted at Pediatric Surgery Department in Bursa Yuksek Ihtisas Training and Research Hospital, after obtaining ethical approval from the University of Health Sciences. We retrospectively reviewed patients' medical records with a preliminary diagnosis of $\mathrm{CC}$ treated in our department between May 2014 and January 2021. We recorded the demographic characteristics such as age and gender, clinical symptoms and signs, MRCP results, and if operated, IOC results and intraoperative gross pathological findings, the treatment procedure performed, and the patients' outcome. Each parent signed a written informed consent form to publish the patients' data and images before submitting the manuscript.

\section{Results}

There were seven patients preliminarily diagnosed with $\mathrm{CC}$ in the study period. We presented the patient data including age, gender, clinical symptoms and signs, the results of the imaging methods used either preoperatively or intraoperatively, together with the treatment procedure performed in Table 1.

\section{Magnetic Resonance Cholangiopancreatography}

MRCP was performed using a $1.5-\mathrm{T}$ system (GE Signa General Electric Medical Systems, Milwaukee, Wis) scanner by a single-shot fast spin-echo (FSE) sequence of 20-30 mm slabs depending on patient size. The 3D images were acquired from these sections, including axial weighted-T2 FSE and oblique-coronal T2 fat-saturated FSE sequences, and images were evaluated on film. Todani classification, used during image interpretation, was: Type-I-Cystic dilatation of the entire common bile duct (CBD) (IA: cystic; IB: fusiform; IC: saccular), Type-II-Diverticulum of the extrahepatic biliary tree, Type-III: Cystic dilatation of the intraduodenal portion of CBD, Type-IV: Multiple cysts of the intrahepatic and extrahepatic biliary tree and Type- $V$ : Isolated intrahepatic cystic disease (Caroli's disease).

Laparotomy, Intraoperative Cholangiography, and Surgical Procedure

The treatment procedure was planned based on MRCP results. Laparotomy was performed through a right subcostal incision. After gross evaluation of the liver and the cystic structure, IOC was performed using a 22-gauge cannula. A purse-string suture was placed on the fundus, and the contrast dye (Urovist ${ }^{\circledR}$ ) solution diluted 1:1 with saline was administered through the cannula. The cystic lesion and findings were documented on X-ray films.

Total excision of the choledochal cyst was performed in patients when IOC revealed a choledochal cyst, and duodenal cyst excision was performed when a duodenal duplication cyst was diagnosed. Rouxen-Y Hepaticojejunostomy (RYHJ) was performed following cyst excision. A liver biopsy was performed when IOC revealed biliary atresia.

\section{Patients}

Patient 1: A 40-day-old boy was admitted with jaundice, abdominal distention, fever, and elevated bilirubin levels. The MRCP result was a Type-II

Table 1. Patients' data regarding age, gender, clinical symptoms and signs, results of the imaging methods, and the treatment procedure performed

\begin{tabular}{lllllll}
\hline Patients & Age & Gender & $\begin{array}{l}\text { Symptoms \& } \\
\text { Signs }\end{array}$ & $\begin{array}{l}\text { MRCP } \\
\text { Result }\end{array}$ & $\begin{array}{l}\text { IOC } \\
\text { Result }\end{array}$ & Treatment Procedure \\
\hline P1 & 40 days & M & J, AD, F & Type-II & Duplication cyst & RNYHJ \\
P2 & 3 years & F & P, F, V & Type-I & Type-I & RNYHJ \\
P3 & 3 years & F & J, P, F, V & Type-IV & Type-I & RNYHJ \\
P4 & 13 years & M & P, V & Type-I & - & Conservative treatment \\
P5 & 5 month & F & J, F, V & Type-I & Type-I & RNYHJ \\
P6 & 1 month & M & J, AD & Type-I & Type-I & RNYHJ \\
P7 & 5 month & M & J, AS & Type-I & Biliary atresia & Liver biopsy \\
\hline
\end{tabular}

MRCP: Magnetic resonance cholangiopancreatography; IOC: Intraoperative cholangiography; RNYHJ: Roux-en-Y Hepaticojejunostomy; AD: Abdominal distention; AS: Acholic stool; F: Fever; J: Jaundice; P: Pain; V: Vomiting 
CC. However, IOC revealed a duplication cyst in the duodenal curve, and duodenal cyst excision was performed (Figure 1A, B, C). The patient experienced no recurrent jaundice or hyperbilirubinemia during two years of follow-up.

Patient 2: A 3-year-old female patient was admitted with recurrent fever, abdominal pain, and vomiting. Leukocytosis and elevated serum bilirubin and amylase levels were present. The patient's abdominal USG showed a cystic dilatation in the portal area measured as $5 \times 4 \mathrm{~cm}$. The MRCP result was a Type-I CC. IOC confirmed a Type-I CC. Total choledochal cyst excision and RYHJ were performed (Figure 2A,B,C).

Patient 3: A 3-year-old female patient was admitted with abdominal pain, fever, vomiting, and dehydration.
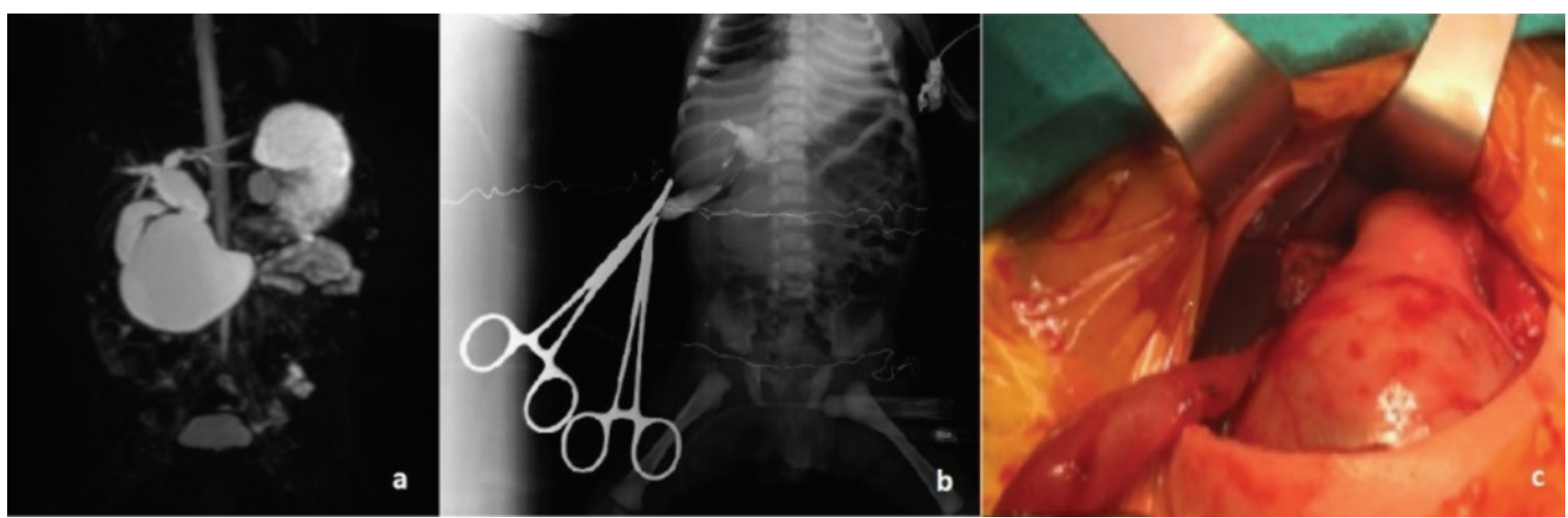

Figure 1. MRCP reported as a Type-II choledochal cyst (a). IOC revealing a duplication cyst at the duodenal curve (b). Intraooperative image of the duodenal duplication cyst (c).

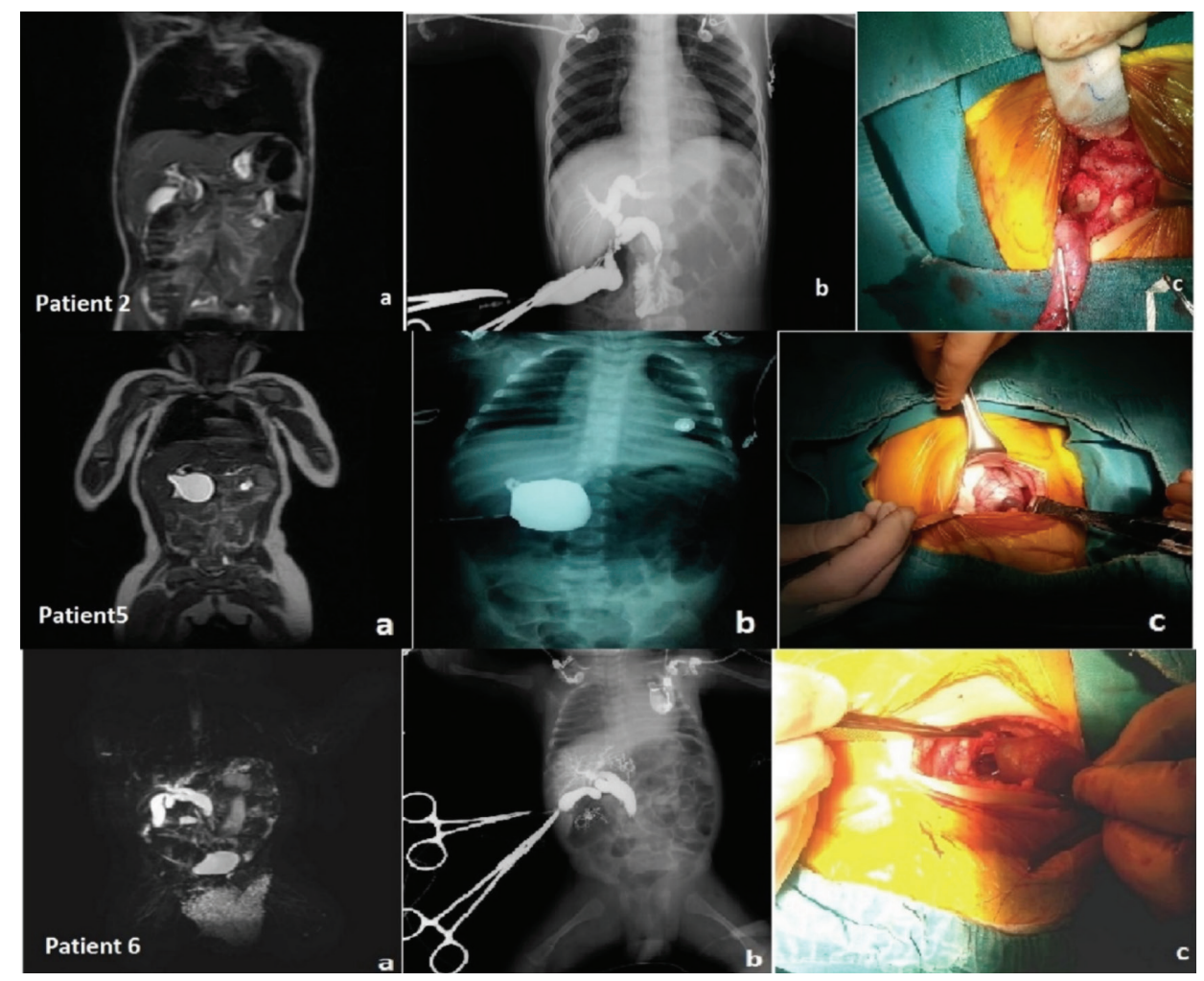

Figure 2. The findings of patients with Type -I choledochal cyst (the patients 2,5 and 6): MRCP showing a Type-I choledochal cyst (a); IOC revealing a Type-I choledochal cyst (b); Intraoperative image of the Type-I choledochal cyst (c). 
She had a medical history involving recurrent cholangitis, impaired liver function tests, and direct hyperbilirubinemia. The patient was lethargic and had second-degree dehydration besides acidotic breathing. The MRCP result was a Type-IV CC. However, IOC revealed a Type-I CC Total cyst excision and RYHJ was performed (Figure 3A,B,C).

Patient 4: A 13-year-old male patient had a history of recurrent hospitalizations in another clinic with abdominal pain, vomiting, impaired liver function tests, and direct hyperbilirubinemia. The patient was referred to our clinic with a previous MRCP result of Type-I CC (Figure 4A). Our physical examination and laboratory investigation revealed no abdominal sign and no elevation of the liver enzyme or bilirubin levels. Since evidence regarding medical history, physical examination, and laboratory evaluation to diagnose $\mathrm{CC}$ were absent in the patient, a hepatocyte-specific magnetic resonance imaging (MRI) was performed, revealing a simple hepatic cyst (Figure 4B), and thus, the patient was treated conservatively.

Patient 5: A 5-month-old female patient with recurrent jaundice and hospitalization history was referred to our clinic with an intraabdominal cystic structure identified by USG, likely to be a Type-I CC $42 \mathrm{X} 40 \mathrm{~mm}$ in size. The MRCP result was a Type-I CC $45 \mathrm{X} 45 \mathrm{~mm}$ in size (Figure 2, Patient 5A). IOC revealed a giant choledochal cyst $80 \times 80 \mathrm{~mm}$ in size and was considered a Type-I CC (Figure 2, Patient $5 \mathrm{~B})$, consistent with the USG and MRCP results, but more significant in size. The patient underwent total choledochal cyst excision and RNYHJ (Figure 2, Patient 5C).
Patient 6: A preterm neonate with 31-week gestational age was admitted to our clinic with weak reactions, jaundice, and abdominal distention caused by an intraabdominal cyst, already diagnosed by antenatal USG. The abdominal USG identified a lobulated, cystic mass $3.5 \times 2 \mathrm{~cm}$ in size, originating from porta hepatis. The MRCP result was a Type-I CC (Figure 2, Patient 6A). IOC confirmed a Type-I CC (Figure 2, Patient 6B), and total choledochal cyst excision and RNYHJ were performed (Figure 2, Patient 6C).

Patient 7:A5-month-old malepatient with prolonged jaundice, acholic stools, and hyperbilirubinemia was admitted to our clinic. The abdominal USG revealed dilatation of the common bile duct. The MRCP result was a Type-I CC (Figure 5A). At laparotomy, the liver had a cirrhotic and rigid nature, macroscopically. A serous fluid-filled cystic structure in the gallbladder line and a fibrotic sac containing no bile were present. The common bile duct did not have any dilatation. IOC was performed, and intrahepatic bile ducts were not visualized (Figure 5B). Biliary atresia was considered as the diagnosis, and a liver biopsy was performed. Because the histopathological diagnosis was consistent with biliary atresia, the patient underwent liver transplantation in the Center for Transplantation (Figure 5C).

\section{Discussion}

The retrospective chart review of our seven cases preliminarily diagnosed with $\mathrm{CC}$, whose ages ranged from 20 days to 13 years, revealed that MRCP was consistent with IOC in three out of six operated

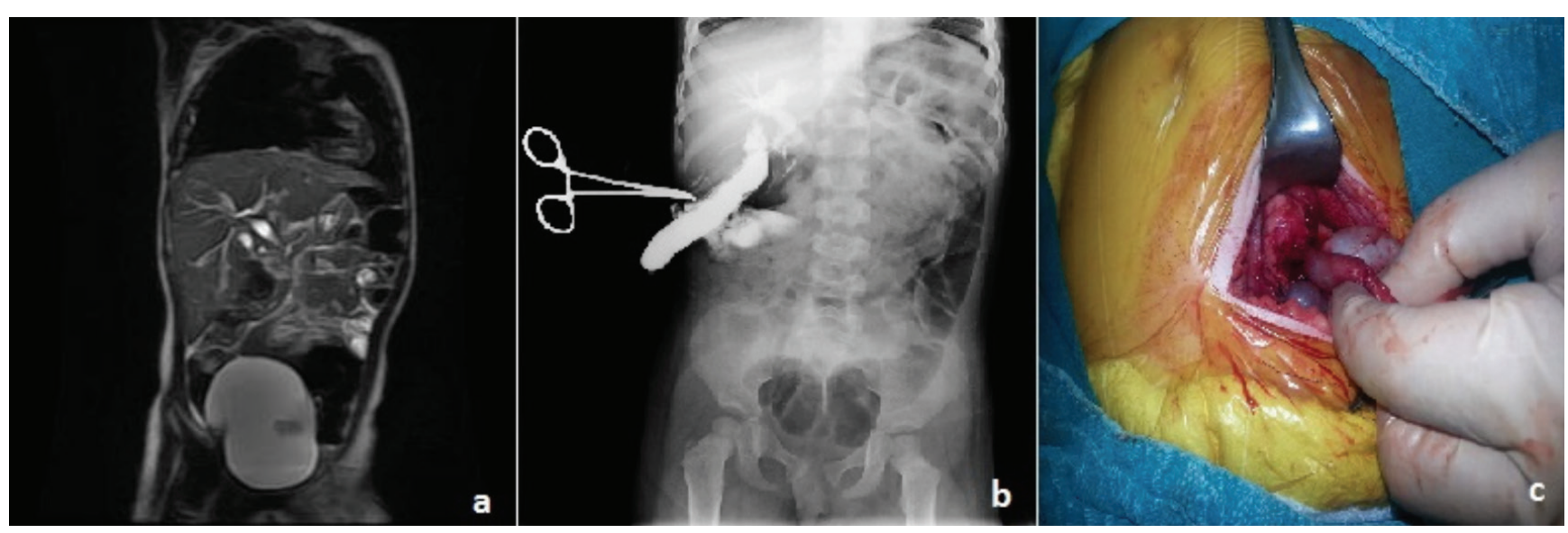

Figure 3a, b, c. MRCP reported as a Type-IV choledochal cyst (a). IOC revealing a Type-I choledochal cyst (b). Intraoperative image of the Type-I choledochal cyst (c). 
cases, both showing a Type-I CC. However, in the three remaining operated cases, their results were inconsistent; the type of reported CC in MRCP (TypeIV) was not similar to the IOC result (Type-I) in one case, another case diagnosed with a Type-II CC in MRCP turned out to be a duodenal duplication cyst at laparotomy, and a case in whom MRCP reported a Type-I CC was diagnosed with biliary atresia with IOC.

The choledochal cyst is a rare choledochal malformation characterized by dilatation of bile ducts in the pancreaticobiliary system with a reported incidence of 1 in 100.000-150.000 live births in the Western population [8,9]. CC manifests itself with various symptoms, signs, and clinical features such as jaundice, palpable right upper quadrant mass, abdominal pain, described as the classical triad, pancreatitis, cholangitis, impaired liver function tests, and biliary cirrhosis $[8,10]$. However, the classical triad of CC has been reported to be present in only $6 \%$

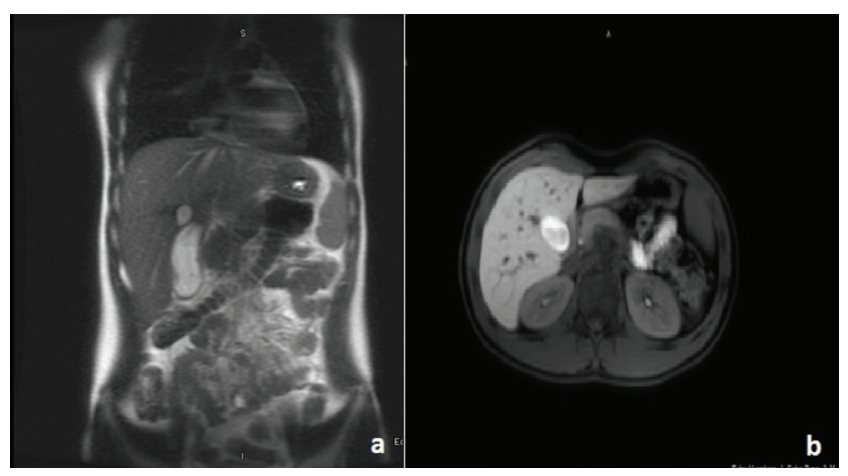

Figure 4A, B. MRCP reported as a Type-I choledochal cyst (A). Hepatocyte-specific MRI with a gadolinium-based agent revealing a simple hepatic cyst (B). of patients [6]. Cholangitis, pancreatitis, impaired liver function tests, and elevated amylase levels have been considered the result of anomalous pancreaticobiliary ducts or functional obstruction of the biliary tree [11]. For this reason, absolute diagnostic precision typically relies upon imaging methods because such clinical features are not specific to choledochal cysts.

MRCP has been considered an improved imaging method for evaluating the pancreaticobiliary duct system by visualizing the entire biliary tract anatomy in adults and pediatric patients, including adolescents [12]. In various publications, MRCP has been claimed to provide diagnostic data on pancreaticobiliary system anomalies since the 1990s and, it was reported that, when present, it could precisely identify the type of CC in pediatric cases, regardless of the patient's age $[13,14]$. Several reports with controversial results regarding MRCP's diagnostic accuracy in the pediatric age group have also been published in the literature. Hamid et al., in their prospective study comparing MRCP with IOC in pediatric aged 30 choledochal cyst cases and 20 cases with cholestatic jaundice, reported that MRCP was effective in delineated choledochal cysts, but its accuracy was only $60 \%$ in showing anomalous pancreaticobliliary ductal union (APBD-union) [15]. They reported that the patients in whom APBD-union was determined by surgery/IOC but not with MRCP preoperatively belonged to the smaller age group than those in whom MRCP was positive for APBD-union. They concluded that pediatric MRCP investigation had boundaries because of bile ducts with a small caliber, poor signal reception, and motion with respiration,

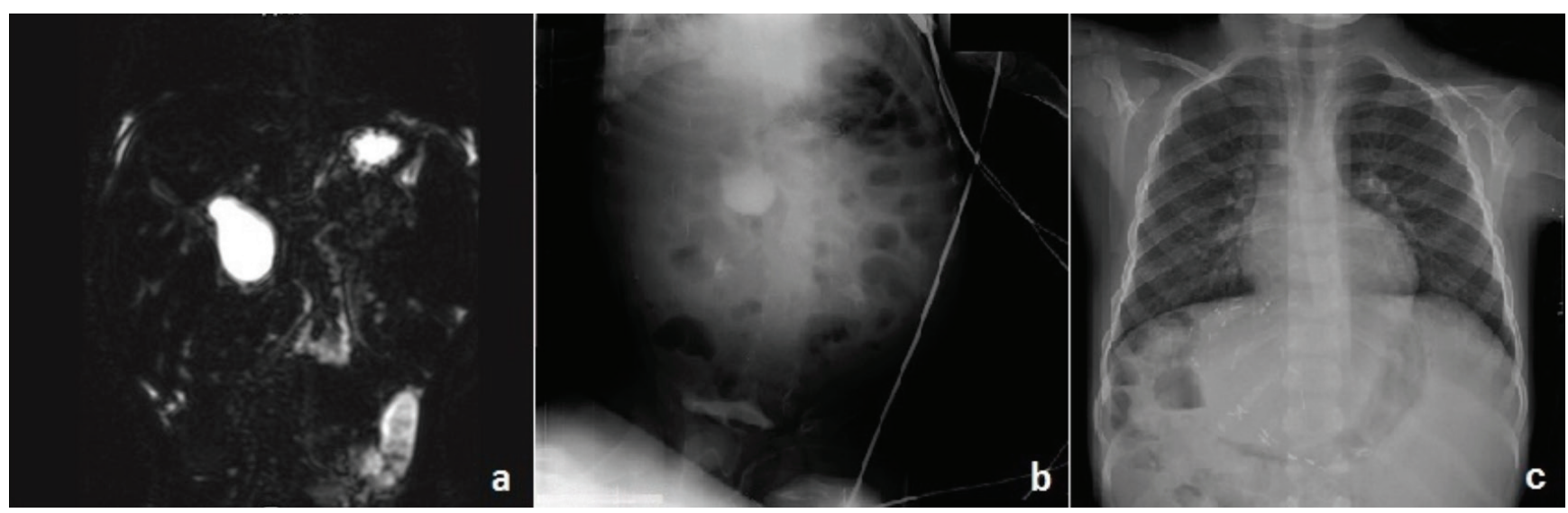

Figure 5A, B, C. MRCP reported as a Type-I choledochal cyst (A). IOC revealing no intrahepatic and extrahepatic bile ducts (B). Abdominal x-ray showing previously inserted metallic stapler stiches for liver transplantation (C). 
intestinal peristalsis, and insufficient sedation [15]. In 2006, Suzuki et al. reported that the pancreaticobiliary system's visualization accuracy significantly differed with age and claimed that MRCP should be the first choice to confirm the diagnosis of $\mathrm{CC}$ in patients aged over two years [16]. Our study revealed a significantly low concordance between the results of MRCP and IOC (3 out of 6 cases). When we analyzed the cases that the two imaging modalities were discordant, we observed that those three cases were aged 40 days, five months, and three years. The last case had a minor discordance regarding only the cyst type (Type-IV in MRCP vs. Type-I in IOC), and when we excluded that 3-year-old patient with such a minor discordance, our remaining two cases were under two years of age, consistent with Hamid et al.'s and Suzuki et al.'s reports $[15,16]$. Regarding the last case in whom a Type-I CC was misinterpreted as a Type-IV CC in MRCP, Murphy et al. had a similar observation and reported that their all discordant results originated from discrimination between the Types I and IV choledochal cysts [17]. Saito et al. reported that the positive predictive value of MRCP was 33\% (6/18), almost half of IOC's predictive value, which was $64 \%$ (7/11), not for pediatric choledochal cysts but for perihilar biliary strictures accompanying them, and they concluded that IOC could visualize such strictures much better than MRCP [7]. Such publications with controversial results emphasize the significance of IOC regarding assessment of cystic lesions of the pancreaticobiliary structures.

Another cause of the discordance determined between the results of two imaging methods might have been the "Satisfaction of Search (SOS) Phenomenon" [18]. According to this concept, when an initial target is successfully identified in radiology, it might reduce the identification probability of a second target; the radiologist might be confident that the mission is accomplished and might not proceed searching for additional abnormalities, resulting in a diagnostic error. This phenomenon might be one cause of discordance in the second, third, and seventh patients in our case series.

Limitations of our study were its retrospective nature and being conducted in a single center with few patients. On the other hand, our study might be considered a support to raise questions about MRCP's preoperative diagnostic accuracy in cystic lesions of the pancreaticobiliary system in the pediatric age group.

\section{Conclusion}

A choledochal cyst is frequently considered as a preliminary diagnosis and assessment of the pancreaticobiliary ductal structures is required in pediatric patients with biliary tract dilatation. MRCP, which is a non-invasive and easily implementable method using no ionizing radiation, is frequently used for evaluation of such cases, and preoperative MRCP images are helpful for management planning, it does not provide a definitive diagnosis of choledochal cyst. Surgeons should be ready to encounter other pathologies and significantly alter their operative planning and approach intraoperatively. Since our results suggested that IOC was very beneficial in our case series, we think that performing a laparotomy/ IOC is required for definitive diagnosis, detailed interpretation of the anatomy, and to guide the treatment, to proceed either medical or surgical. Since medical technology is continuously developing, prospective and multi-center studies with large sample sizes should be performed to decide about the actual accuracy of MRCP.

\section{Ethics}

Ethics Committee Approval: This retrospective study was conducted at Pediatric Surgery Department in Bursa Yuksek Ihtisas Training and Research Hospital, after obtaining ethical approval from the University of Health Sciences.

Conflict of Interest: No conflict of interest was declared by the authors.

Financial Disclosure: The authors declared that this study received no financial support.

\section{References}

1. Abbey P, Kandasamy D, Naranje P. Neonatal Jaundice. Indian J Pediatr 2019;86:830-41.

2. Aggerwal N, Menon P, Rao KL, Sodhi KS, Kakkar N. Comparative analysis of spherical and fusiform choledochal cyst based on threedimensional magnetic resonance cholangiopancreatography, biliary amylase, and histopathological examination. J Indian Assoc Pediatr Surg 2015;20:128-32.

3. Vater A, Ezler CS. De scirrhis viscerum occasione sectionis viri tympanite defuncti. Dissertation. 1723.

4. Todani T, Narusue M, Watanabe Y, Tabuchi K, Okajima K. Management of congenital choledochal cyst with intrahepatic involvement. Ann Surg 1978;187:272-80. 
5. Friedmacher F, Ford KE, Davenport M. Choledochal malformations: global research, scientific advances and key controversies. Pediatr Surg Int 2019;35:273-82.

6. Stringer MD, Dhawan A, Davenport M, Mieli-Vergani G, Mowat AP, Howard ER. Choledochal cysts: lessons from a 20 year experience. Arch Dis Child 1995;73:528-31.

7. Saito T, Terui K, Mitsunaga T, Nakata M, Yoshida H. Significance of imaging modalities for preoperative evaluation of the pancreaticobiliary system in surgery for pediatric choledochal cyst. J Hepatobiliary Pancreat Sci 2016;23:347-52.

8. Miyano T, Yamataka A, Li L. Congenital biliary dilatation. Semin Pediatr Surg 2000;9:187-95.

9. Soares KC, Arnaoutakis DJ, Kamel I, Rastegar N, Anders R, Maithel S. et al. Choledochal cysts: presentation, clinical differentiation, and management. J Am Coll Surg 2014;219:116780.

10. Saluja SS, Mishra PK, Nayeem M, Nag HH. Choledochal cyst with chronic pancreatitis: presentation and management. JOP 2010;11:601-3.

11. Jung SM, Seo JM, Lee SK. The relationship between biliary amylase and the clinical features of choledochal cysts in pediatric patients. World J Surg 2012;36:2098-101.

12. Yoon JH. Magnetic resonance cholangiopancreatography diagnosis of choledochal cyst involving the cystic duct: report of three cases. Br J Radiol 2011;84:18-22.
13. van Heurn-Nijsten EW, Snoep G, Kootstra G, Greve JW, Forget $P$, van Heurn LW. Preoperative imaging of a choledochal cyst in children: non-breath-holding magnetic resonance cholangiopancreatography. Pediatr Surg Int 1999;15:546-8.

14. Yamataka A, Kuwatsuru R, Shima H, Kobayashi H, Lane G, Segawa $\mathrm{O}$, et al. Initial experience with non-breath-hold magnetic resonance cholangiopancreatography: a new noninvasive technique for the diagnosis of choledochal cyst in children. J Pediatr Surg 1997;32:1560-2.

15. Hamid R, Bhat NA, Baba AA, Shaheen F, Ahmad G. Comparison of MRCP with Intraoperative Cholangiography in Paediatric Choledochal Cyst and Biliary Atresia. Gastroenterol Pancreatol Liver Disord 2017;4:1-9.

16. Suzuki M, Shimizu T, Kudo T, Suzuki R, Ohtsuka Y, Yamashiro $\mathrm{Y}$, et al. Usefulness of nonbreath-hold 1-shot magnetic resonance cholangiopancreatography for the evaluation of choledochal cyst in children. J Pediatr Gastroenterol Nutr 2006;42:539-44.

17. Murphy AJ,Axt JR, Crapp SJ, Martin CA, Crane GL, Lovvorn HN 3rd. Concordance of imaging modalities and cost minimization in the diagnosis of pediatric choledochal cysts. Pediatr Surg Int 2012;28:615-21.

18. Fleck MS, Samei E, Mitroff SR. Generalized "satisfaction of search": adverse influences on dual-target search accuracy. J Exp Psychol Appl 2010;16:60-71. 